\title{
Green Architecture Concept Application On USU Kwala Bekala Library
}

\author{
A. D. Nasution*and S. Handiningtyas \\ Architecture Department, Faculty of Engineering, Universitas Sumatera Utara, Medan, Indonesia \\ *email: a.delianur@usu.ac.id \\ Submitted: 14 January 2020 Revision: 24 January 2020 Online: 30 January 2020
}

\begin{abstract}
The library is one of the building functions needed in the university's development standards. A library serves as a place to find information and collections as well as an educational recreation place. Not only providing facilities for the academic community, but Library also expected to be useful for all people, especially those in the surrounding area. For this reason, the supporting area of Science Techno Park which is an area for the development of economic and educational activities in USU Kwala Bekala campus and its surroundings chooses Library as one of its facilities. In USU Kwala Bekala master plan, the location of Library is in the entrance zone with $16 \mathrm{Ha}$ area. This zone is the gateway of USU Kwala Bekala area so the concept of "building as a gate" is forming the building mass. The site forms two separate parts due to its area which surrounded by the main road and separated by other collector roads. The goals of this project are how to design a campus environment that cares for the surrounding environment, can provide comfort to its users, and can create sustainable buildings. After analyzing and implementing the concept of green architecture, the final design concept are two building masses connected with sky bridge which can accommodate 723 seats, windows and inner court to allow the airflow and natural light enters the rooms, secondary skin and vines as its facade to buffer over sunshine and noises, water and trash recycling treatment to reduce clean water use, and solar panel as additional electricity energy.
\end{abstract}

Keywords: architecture, campus, green, library, Technopark.

\section{INTRODUCTION}

Universitas Sumatera Utara is currently experiencing an increasing number of enthusiasts so that the estimated number of USU students will experience a rapid increase in the future. If the increasing number of students is carried out, then USU will plan the campus expansion development at Kwala Bekala with a land area of around $300 \mathrm{Ha}$ [1].

Science Techno Park is one of the areas in the USU Kwala Bekala Campus that facilitates the growth and development of industries, especially small-medium-scale industries based on innovation through incubation and spin-off processes in addition to providing services for industry in a specifically prepared region. In the design of USU Kwala Bekala Science Techno Park area, there is several supporting facilities such as research and education center, open mall and business hotel, library, technology and arts center, auditorium, and information systems center. The library is one of the functions of supporting buildings in the USU Kwala Bekala STP area which serves as a supporter of academic and research activities [2].

USU Kwala Bekala also has principles in its planning and design masterplan: to creating a campus that is energy efficient, healthy and environmentally friendly. Therefore the function of the building in the USU Kwala Bekala was designed using green architecture theme.

The design plan of USU Kwala Bekala campus is by applying the concept of Science Techno Park (STP). The STP area aims to create a permanent link between universities (academics), industry or business and government. An understanding of the USU Kwala Bekala master plan's concept is needed to begin the design study of one of the building functions in it. Meanwhile the location of USU Kwala Bekala campus is in Pancur Batu 
District, Deli Serdang, around $7.4 \mathrm{~km}$ from USU Padang Bulan campus.

The distribution of macro zones in USU Kwala Bekala includes support zone, academic zone, oil palm handling laboratory zone, reservoir, livestock laboratory zone, horticultural laboratory and flower garden zone, and education zone. In this macro zone, there is a micro-zone called Science Techno Park. This micro-zone includes factories, clubhouse, field, open stadium, gym and jogging track, multifunction building, mosque, shop houses and Pendapa, dormitory, training and education center, business hotel and open mall, auditorium, technology, and art center, library, and information system center (Figure 1 and 2) [1]. As for this occasion, the author will explain the design of university library within the USU Kwala Bekala's STP area.

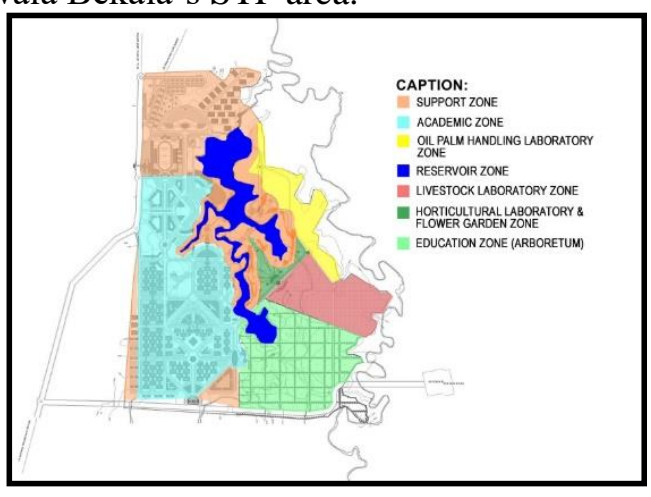

Figure 1. Macro Master plan of USU Kwala Bekala

(Source: Master plan of USU Kwala Bekala)

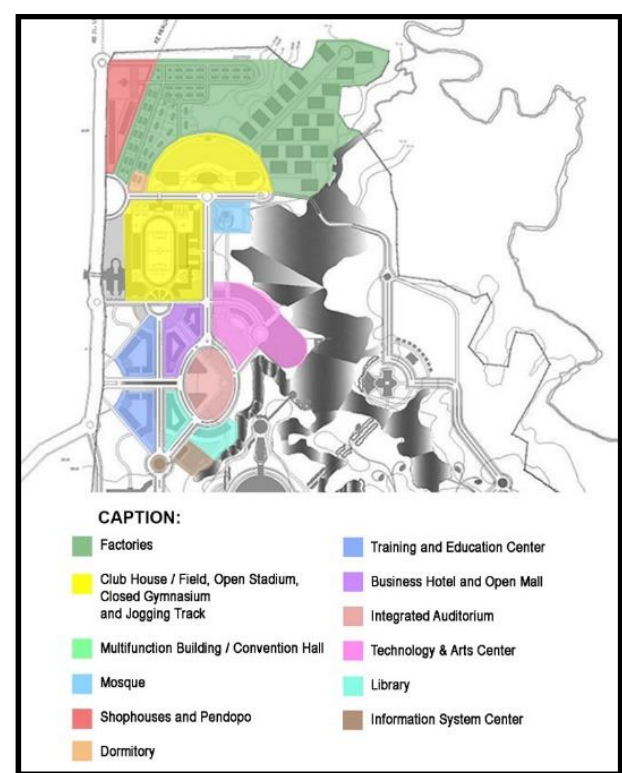

Figure 2. Micro Master plan of STP USU Kwala Bekala

(Source: Master plan of USU Kwala Bekala)
The Ministry of National Education (Depdiknas) has determined the functions of the university library. The first function is a library as an educational function which means academics' learning resource. The second function is a library as an information function where the library uses as the source of any information. The third function is a library as a research function where the library prepares materials to conduct research and study of science, technology, and art. The fourth function is a library as a recreation function where the library must provide a recreational collection that is meaningful to build and develop the creativity, interest, and innovation power of its user. The fifth function is a library as a publication function where the library should also help to publish the work produced by the academics community. The sixth function is a library as a deposit function where the library can be a deposit center for all the creations and knowledge produced by academics community. The last is a library as an interpretation function where the library should have carried out studies and added value to the information sources which it has to assist users in carrying out the Tri-Dharma Perguruan Tinggi (the university's main responsibilities of education, research, and community service) [3].

UI Green Metric Guideline is a benchmark of USU Kwala Bekala Library design because of its principles which has the similarity as Green Architecture's. The first assessment point is arranging layout and infrastructure plans for universities which are a general description of the campus propensity for a green environment so that a university can be approved as a green campus or not with the aim of triggering its area to create more open spaces and maintain sustainable environment and energy. The second point is universities must be concerned about energy and climate change because they are expected to be able to increase energy efficiency efforts for their buildings to maintain nature and save energy sources. The third point is universities must conduct a waste recycling program to reduce the use of paper and plastics. The fourth point is universities must make efforts in reducing water use, improving conservation programs, and protecting communities by conducting water conservation programs, water recycling programs, water use efficiency programs, and the use of processed water to support the 
continuity of sanitation activities. The last point is universities must provide environmentallyfriendly public transportation which can reduce more carbon pollution around campus and also give proper facilities for pedestrians [4].

\section{METHODS}

The design idea arises after knowing the prediction of the high number of students entering USU in 2020. The design of this library is based on the chosen theme of Green Architecture, data; requirements; standards; and needs that have been set by law, Indonesian National Standards, Architect's Data, Time Saver, Metric's Book, UI Green Metric Guideline 2017, etc. In this design process it takes an analysis process which is a process in the form of observation, selection of subjects based on criteria, and produce solutions or alternatives based on objects, sites, and themes that have scientific characteristics.

\section{RESULTS AND DISCUSSION}

Based on USU Kwala Bekala master plan Planning Book, a list of faculties will be attached to the USU Kwala Bekala in the form of 47,987 students 1]. The assumption of a comparison between the number of students and the number of seats owned by the library is from the results of a literature study on the University of Gadjah Mada Library which has a ratio of 1 seat per 57 students [5]. For that, the calculation of seats number provided at the USU Kwala Bekala Library requires a total of 723 seats to fulfill visitors' needs.

\section{Building Mass Concept}

The chosen mass form is following the formation of a site to support the concept of building as a gate. Extensive land is expected to form facades in this area to create the streetscape. After that, by the green architecture concept, the middle part of the building layout on the left is removed to serve as the inner court for the green space so that the masses are not massive. Then the mass is raised to make it into three levels building. Only for the eastern building, the third level of mass is rather inclined towards the lake to maximize the view of the lake. Lastly, give a link between the two masses with sky-bridge (Figure 3).

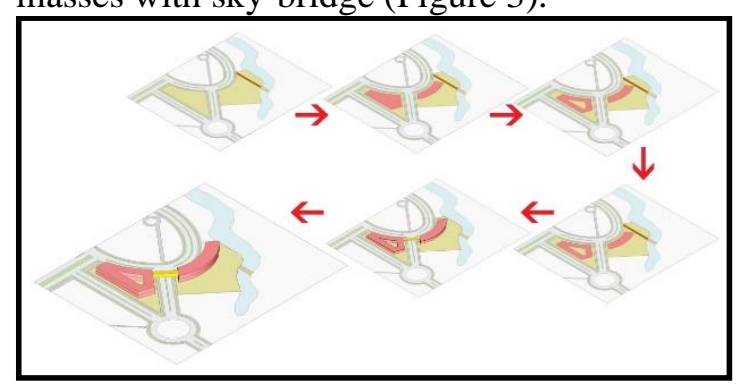

Figure 3. Building Mass with Building as a Gate Concept

\section{Outdoor}

Drop off area is located at the back of the building because of its location is close to the parking lot. At the eastern site, the plaza design applied to the entrance area. The design of entrance and drop off area in the east building also looks more prominent than the western buildings so that visitors will be easier to recognize the location of the main building. Circulation was also designed with a loop system to make it easier for visitors to find parking spaces and drop-off the passengers or warehouse goods. While the loading dock point is located at the outer side of the building to make it easier for officers to distribute new items coming into the storage warehouse (Figure 4 and 5).

Pedestrian is close to the collector's road and greening. For the west side building, pedestrians enter get into the main door in the north. Whereas on the east side, the pedestrian can enter the building from the west door of the bus stop, the north entrance from the drop-off area, and the east entrance from the pedestrian and terrace (Figure 6).

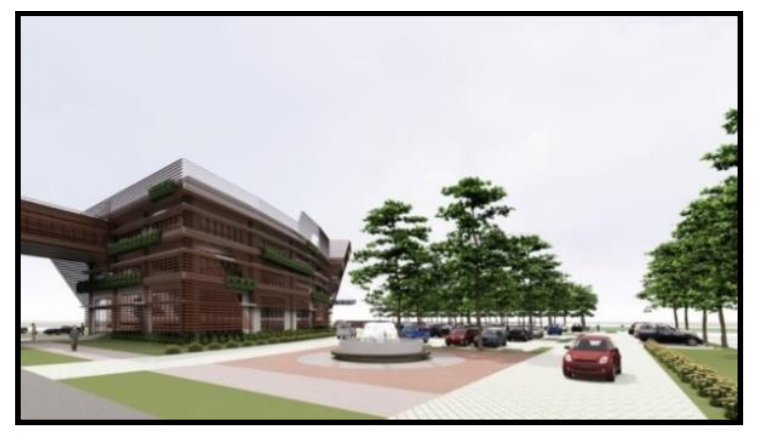

Figure 4. Eastern Building Entrance Scheme that Impressed More Receiving 


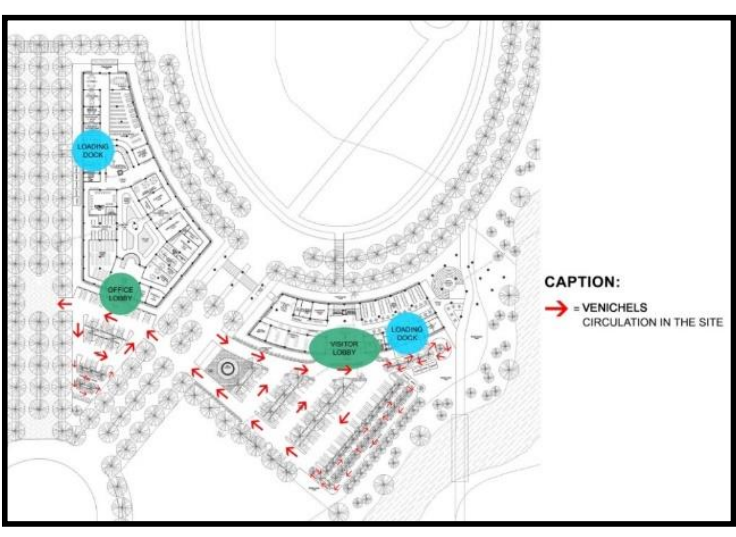

Figure 5. Transportation Circulation Concept

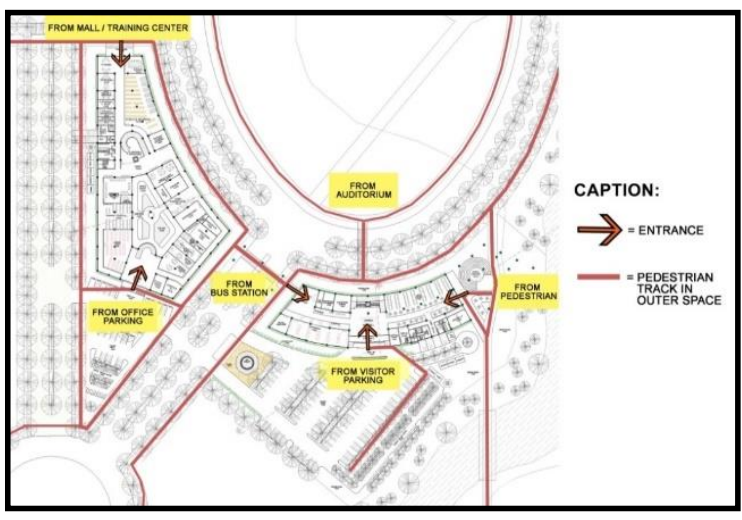

Figure 6. Pedestrian Circulation Concept

\section{Indoor}

The officer area is located on the east side of the building while the facility and service area is more dominant on the west side of the building because the western area is intended for visitors. Supporting collection space area is an area that is more often handled by officers and managers so that its location is close to the worker area. While on the second floor is focused on the collection and reading area because this area requires a calmer atmosphere. Both buildings are connected to the sky bridge to integrate space programs so that they can be accessed easily. The service area is placed at the outer side near the loading dock parking and utility area to facilitate all service activities (Figure 7, 8, and 9.)

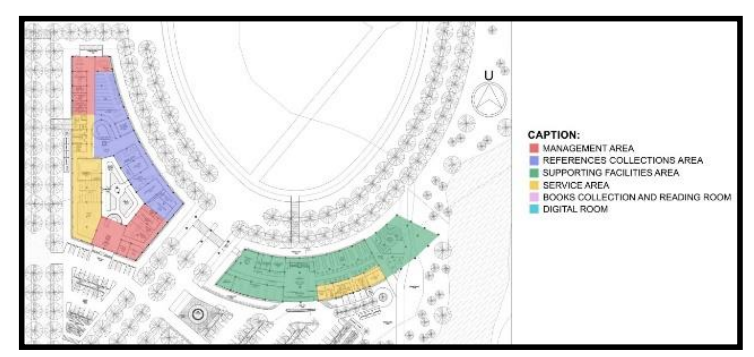

Figure 7. First Floor Zoning

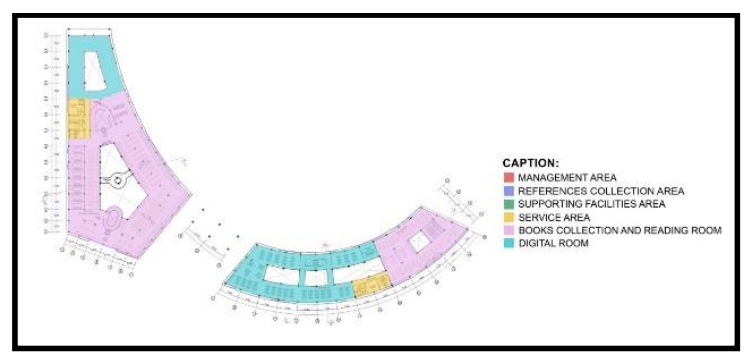

Figure 8. Second and Third Floor Zoning

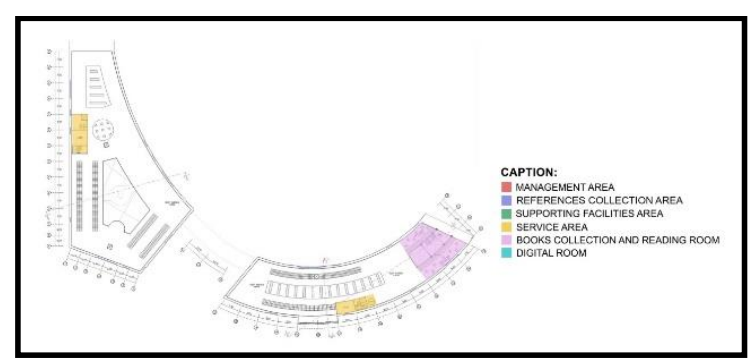

Figure 9. Roof Garden Floor Zoning

Circulation of western building's first level located at the outer side of building layout to becomes noises buffer so the rooms will not be noisy. In the inner court, there is also a circulation for outdoor activities of visitors and officers. While the hallway of the eastern building located in the middle of building layout with the void at the top of it to make a gigantic scale of library building (Figure 10 and 11).

On the second floor, the western building has a outer shell circulation so that the orientation of the reader leads to the inner court. While the location of eastern building's visitor track is also in the middle area around the void to maximize the view towards the reservoir (Figure 12). 


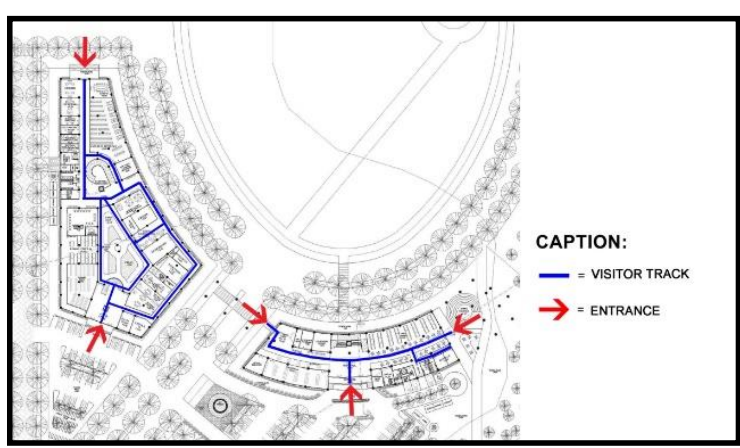

Figure 10. Indoor Circulation of First Level (visitors)

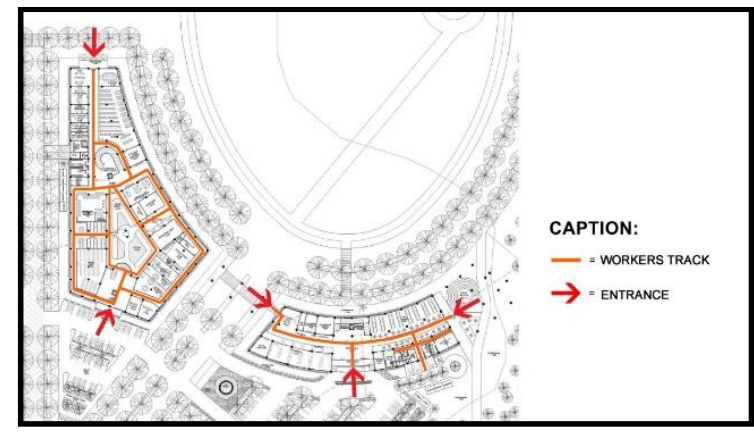

Figure 11. Indoor Circulation of First Level (officer)

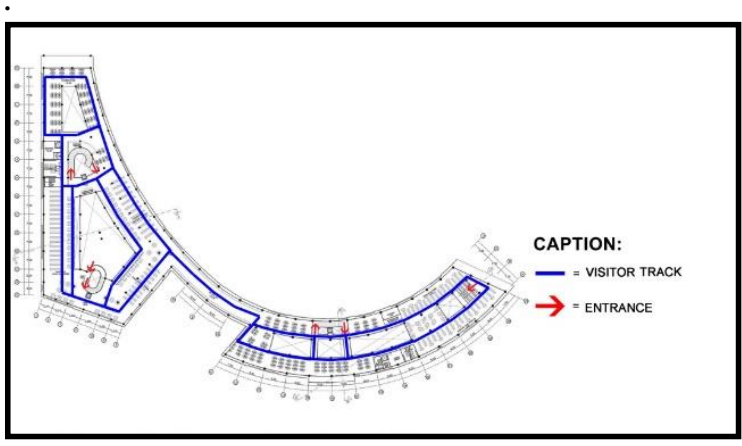

Figure 12. Indoor Circulation of Second Level

(visitors)

\section{Natural Lighting Concept}

This building uses glass walls with lowemissivity technology where the transparent properties can continue the sunlight and reduce heat from the sunlight which entering the building. There are also skylights in the middle of the eastern building so that natural sunlight can enter the building. The space under it is a void that can make the big scale atmosphere inside the library (Figure 13).

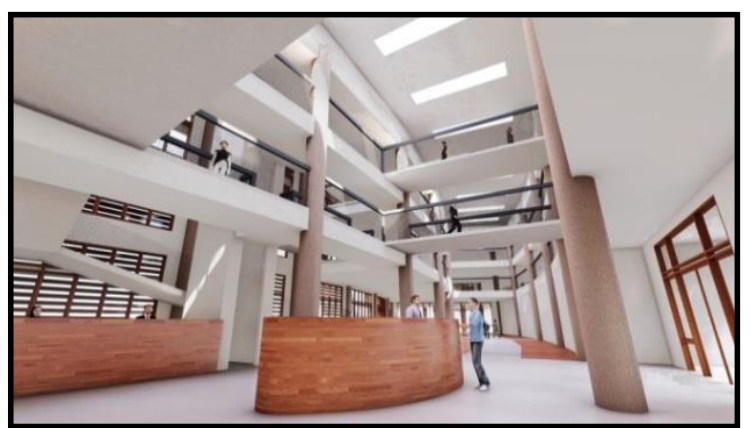

Figure 13. Skylight Concept in the Void with its Natural Light

The inner court is placed in the core of the east side building so that the rooms' orientation is to the greening area. The function of greening and artificial ponds in the inner court is as a calming effect for building users in the rooms. Besides that, sunlight can also enter the inner court and pass it to the inner building. Providing opportunities for air movement in the inner court can also provide a low temperature inside the building (Figure 14).

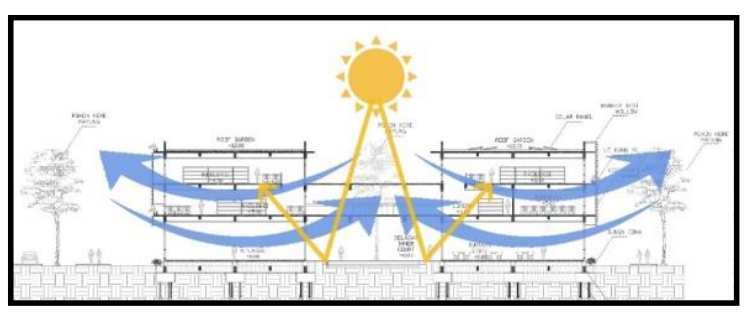

Figure 14. Inner Court Scheme which Explains the Movement of Natural Air and Lighting

\section{Sunlight Buffer Concept}

The concept of sunlight buffer is by applying an overhang as a reflection of the sunlight so that it can be spread evenly throughout the room. There are also secondary skin and vines as the penetration of light to make the reading room stay bright, not hot, and comfortable (Figure $15)$. 


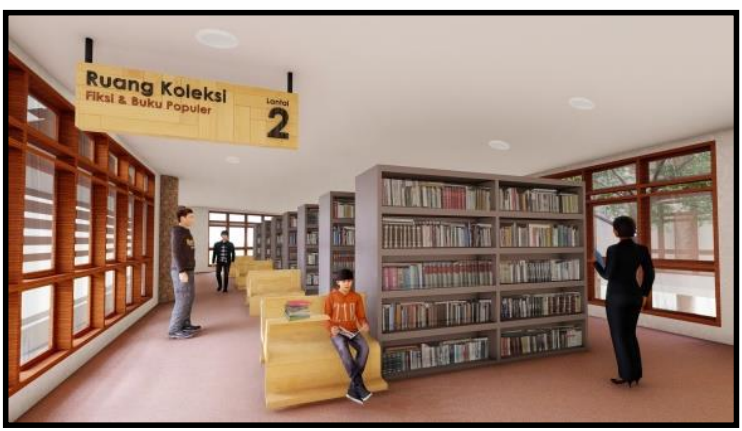

Figure 15. Reading Room Scenery with its Natural Lighting

\section{Noises Buffer Concept}

The plant vegetation in the green lane which is located side by side with the collector's road can overcome main noise from the collector's road. With the sound buffer, the noise will decrease, and it will also increase the concentration of library user while reading (Figure 16).

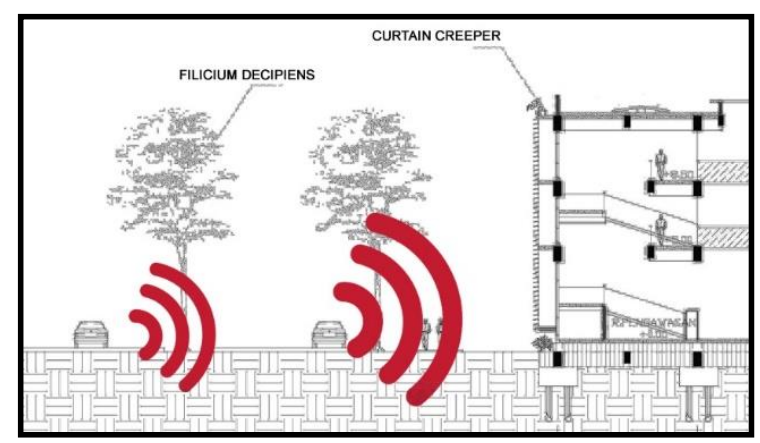

Figure 16. Noises Buffer with Trees

\section{Roof Garden Concept}

The applied roof garden adjusts to the concept of green architecture. The function of the roof garden is to reduce heat in the room below, reduce pollution and noise, and as a green open space for recreation area (Figure 17).

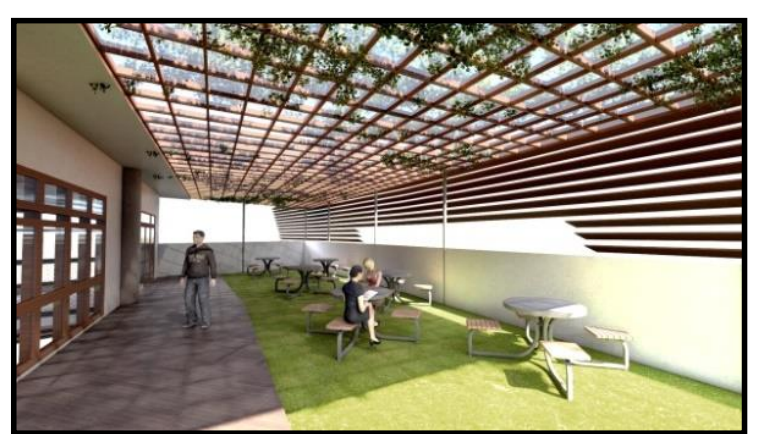

Figure 17. Grass as Greening at the Roof

Garden

\section{Universal Design Concept}

The ramp is applied to the Library design to facilitate the movement of persons with disabilities. The ramp is also placed at several points to make it easy to access (Figure 18).

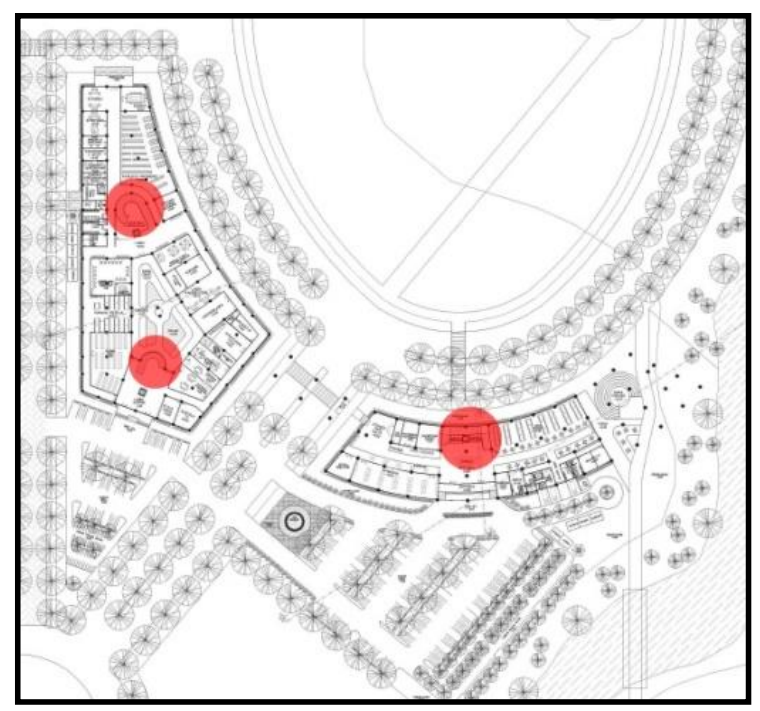

Figure 18. Accessible Ramp Point Locations to Make Visitors Walk Easily

\section{Transportation Concept}

Shuttle buses that continuously surround the road in USU Kwala Bekala area have some bus stops at several points. In the Library building, the bus stop is placed under the skylight and brings the visitors directly to the entrance of the building without being exposed to heat and rain (Figure 19). 


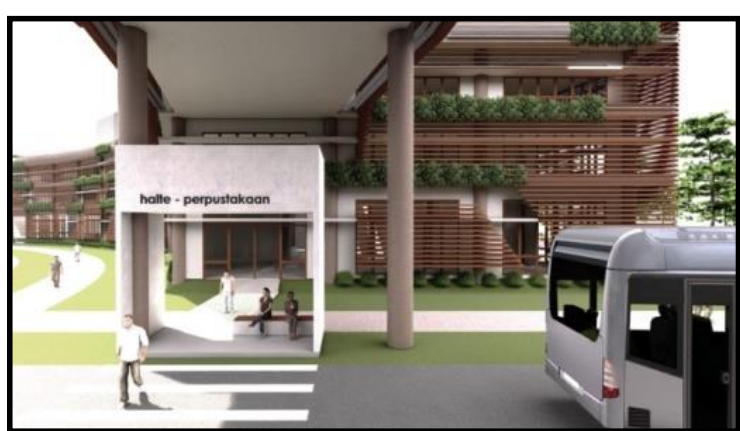

Figure 19. Bus Stop which Oriented Directly at the Entrance

\section{Water Treatment Concept}

In addition to using water from the clean water resources or local water company, this building can manage filtered rainwater for its water use. The filtration tank will filter wastewater from building and drainage before being drained into the drainage duct on the collective road and processed again in the USU Kwala Bekala WWTP or Wastewater Treatment Place (Figure 20).

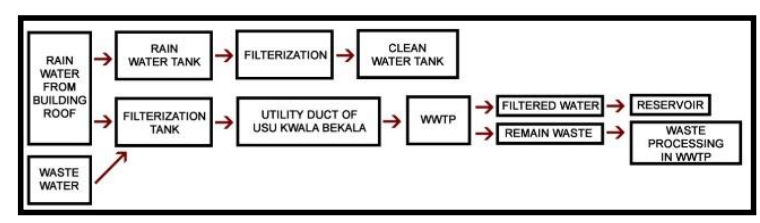

Figure 20. Wastewater Scheme with Water Treatment System

\section{Solar Energy as an Electricity Source Concept}

Apart from local electricity source which named State Electricity Company, solar panel utilization is applied to this building to increase electricity supply from solar energy and reduce the use of electricity from State Electricity Company (Figure 15).

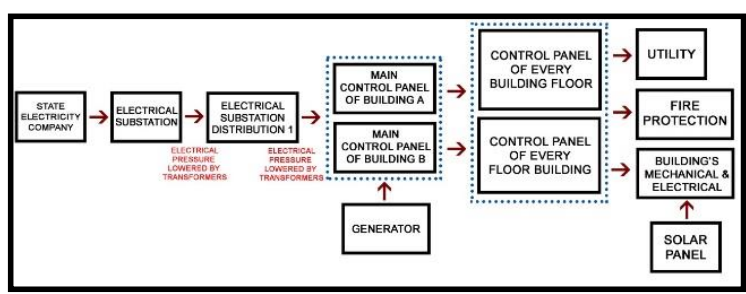

Figure 15. Electricity Flow Scheme with Solar Panel as Additional Electricity Supplies

\section{CONCLUSION}

USU Kwala Bekala Library is expected to be able to support the activities of academics in seeking information for educational, research and community service needs. This building is open to the public. Therefore, in addition to providing scientific books to support education, the Library also supply the collection of popular books and fiction books. Thus, this Library also can be used for public recreation. The goodunique design of rooms and its interior arrangement program are expected to increase reading interest among students and the public.

In terms of design, Green Architecture is the basic theme to support USU Kwala Bekala Campus's vision and mission: to create an environmentally friendly campus environment. Besides, this theme is also suitable for tropical climate such as Pancur Batu. The Green Architecture principles also expected to have impacts on people, buildings and its surrounding environment.

\section{ACKNOWLEDGMENT}

This article is written by researchers who are partly funded by the University of Sumatera Utara and was given out as a donation to the government to preserve and improve the value of design, local wisdom, arts and ethnic.

\section{REFERENCES}

[1] Universitas Sumatera Utara, Perencanaan Masterplan Kampus USU Kwala Bekala. Medan, Indonesia, 2006.

[2] Syam, Bustami, dkk, "The Development of Kwala Bekala Technobiz Park (KBTP) University of Sumatera Utara," 2017.

[3] Departemen Pendidikan Nasional RI, Perpustakaan Perguruan Tinggi: Buku Pedoman, 3rd ed. Jakarta, Indonesia: Depdiknas, 2004.

[4] Universitas Indonesia. (2015) UI Green Metric World University Ranking. [Online]. http:/greenmetric.ui.ac.id/

[5] Perpustakaan Universitas Gadjah Mada. (2018) Profil Perpustakaan Universitas Gadjah Mada. [Online]. lib.ugm.ac.id 
